\title{
The Dispute Settlement Function of the International Court of Justice in Croatia v. Serbia
}

Cecily Rose"

\section{Introduction}

This chapter revisits a central premise of the public law theory of adjudication, namely, the view that the traditional understanding of courts as dispute settlers is inadequate. Admittedly, the function of international courts is larger than the settlement of disputes, and in this sense the traditional understanding is incomplete. International courts are undoubtedly more than "mere instruments of dispute settlement whose activities are justified by the consent of the states that created them and in whose name they decide" ". International courts can also act as law-makers, as promoters of global interests, as institutions within larger legal regimes, and also as institutions that exercise public authority. To an extent, the function of an international court is in the eye of the beholder, whether a judge, a scholar, a diplomat, or a member of the public. Each of these actors may perceive a given judgment or award through a particular lens. A judgment may strike a judge as an opportunity for the court to promote global interests, while an academic, observing from the outside, may primarily understand the same judgment as an instance of law-making. In light of the many ways in which international courts may be perceived, the dispute settlement account does indeed paint only part of the picture.

This contribution argues, however, that the dispute settlement function of international courts merits a more nuanced account. Before we set aside the conception of courts as instruments of dispute settlement, in search of a more satisfactory explanation of the role that international courts are playing today, some of the finer aspects of their dispute settlement function ought to be detailed. This chapter therefore offers a critique of the

* Assistant Professor of Public International Law, Grotius Centre for International Legal Studies, Leiden Law School. The author is grateful to Fernando Lusa Bordin for his comments on an earlier version of this piece.

1 Von Bogdandy, A. and Venzke, I. (2014), In Whose Name? A Public Law Theory of Adjudication. Oxford: Oxford University Press, 1. 
premises of the public law theory of adjudication, by sketching a more complex picture of the dispute settlement function. The focus of this discussion will be on the International Court of Justice (Court or ICJ), the longest-standing international judicial institution, which can be fairly described as generally embracing a "state-centric" conception of courts as instruments of dispute settlement. ${ }^{2}$ The Court's contentious jurisdiction is, after all, limited to inter-state disputes, and depends on states explicitly consenting to the Court's settlement of their disputes. Despite the importance of non-state actors in contemporary international relations, the Court, of course, has no jurisdiction over such entities. Moreover, the Court is best positioned for the settlement of bilateral rather than multilateral inter-state disputes. At times the Court has taken a strict approach to interventions by third states, and to the Monetary Gold principle, which precludes it from ruling on the rights or obligations of a third party that has not consented to its jurisdiction.

However, such an account of the ICJ as an instrument of dispute settlement does a disservice to this institution by focusing on what the Court is not. The Court is not open to non-state actors or to amicus curiae. It is relatively closed to third-party interventions and it is ill-suited to the settlement of multilateral disputes. Highlighting the Court's fundamental limitations as a judicial institution does little to advance our understanding of how the Court actually contributes to the settlement of disputes in the inter-state, mostly bilateral, cases that come before it. How does the Court carry out its role as an instrument of dispute settlement and what does this tell us about its judicial function?

A closer look at the practice of the Court shows us, for example, that its role in dispute settlement is not necessarily limited to the issuance of judgments that resolve legal disputes between states. In fact, in some cases, the manner in which the Court exercises its functions causes it to resemble other forms of dispute settlement listed in Article 33 of the UN Charter, such as inquiry or conciliation. In the North Sea Continental Shelf cases, for example, the Court's approach to the dispute arguably resembled the approach of a conciliation commission. At the behest of the parties, the Court did not actually decide the underlying dispute between the Netherlands, Germany, and Denmark about the course of their maritime boundaries, but instead laid out the factors to be taken into account by the parties in their subsequent negotiations, much as a conciliation commission

2 Ibid., 29, 36-43. 
would make recommendations. ${ }^{3}$ The Court can also play an important role in encouraging other forms of dispute settlement, such as negotiations. The prospect of imminent oral proceedings before the bench, for example, has helped to bring about the resolution of disputes through negotiations. Without even issuing a judgment, the Court can help to catalyze stalled negotiations by simply representing a less desirable dispute settlement method, over which the disputing parties exercise relatively little control. ${ }^{4}$

The remainder of this chapter pursues the argument that the Court, in its February 2015 judgment in Application of the Convention on the Prevention and Punishment of the Crime of Genocide (Croatia v Serbia), played a role similar to that of a fact-finding body. ${ }^{5}$ A controversial jurisdictional maneuver by the Court in its judgment on the merits allowed it to engage with the parties' factual allegations about the commission of genocide during the conflict between Croatia and Serbia in the early to mid-1990s. Without ruling on what it ought to have characterized as a jurisdictional question, the Court went on to issue a lengthy judgment that covered disputed facts at great length, in a manner arguably reminiscent of a commission of inquiry. In doing so, the Court gave less weight to the issue of consent than one might expect based on the standard, state-oriented account of the Court as an instrument of dispute settlement. The Court's approach was perhaps motivated by its awareness of the sensitivity and importance of the case to the governments and the populations of the two disputing parties, and the relatively great length of time that the case had been on its docket. These considerations fit uneasily with the state-centered understanding of the Court's function as an instrument of dispute settlement, and should perhaps cause us to revisit this account. The following case study is thus geared towards painting a fuller, more detailed picture of the Court as an instrument of dispute settlement-an account that recognizes the Court's sometimes flexible approach towards consent, as well as the varied roles that it can play in dispute settlement.

This chapter begins with a description of the Court's jurisdictional rulings in Croatia v Serbia (Part 2), followed by a critique of the Court's jurisdictional maneuver (Part 3). The Chapter concludes by considering the

3 North Sea Continental Shelf (Federal Republic of Germany v. Denmark; Federal Republic of Germany $v$. Netherlands), Judgment, ICJ Reports 1969, 3.

4 See, e.g., Aerial Herbicide Spraying (Ecuador v Colombia).

5 Application of the Convention on the Prevention and Punishment of the Crime of Genocide (Croatia v Serbia), Preliminary Objections, Judgment, ICJ Reports 2015, 3. 
fact-intensive character of this judgment, and its broader implications for the ICJ as an institution of dispute settlement (Part 4).

\section{The Court's Jurisdictional Rulings in Croatia v Serbia}

The Court's 2015 judgment on the merits in Croatia v Serbia was the culmination of sixteen years of litigation involving multiple challenges by Serbia to the Court's jurisdiction. In its Application instituting proceedings in July 1999, Croatia alleged that Serbia was responsible for breaching the Genocide Convention in Croatia between 1991 and 1995. ${ }^{6}$ Serbia responded with counter-claims likewise alleging that Croatia was responsible for breaches of the Genocide Convention in the Republic of Serbian Krajina in $1995 .^{7}$

In 2002, however, Serbia also raised three preliminary objections to the jurisdiction of the Court and the admissibility of Croatia's claims. In its 2008 judgment on preliminary objections, the Court rejected Serbia's first and third preliminary objections, leaving only the second preliminary objection for the merits. ${ }^{8}$ Serbia's second objection concerned the Court's jurisdiction ratione temporis, or temporal jurisdiction-an unusually complex issue in this case due to the dissolution of the former Yugoslavia and the changing status of Serbia as a state in the 1990s. Serbia asked the Court to declare inadmissible and outside of the Court's jurisdiction the claims by Croatia that were based on acts or omissions that took place before the Federal Republic of Yugoslavia (FRY) came into existence on 27 April 1992. Serbia argued that because any acts or omissions occurred before the FRY became a State and also a party to the Genocide Convention, they fell

6 Application Instituting Proceedings, Application of the Convention on the Prevention and Punishment of the Crime of Genocide (Croatia v. Yugoslavia) 2 July 1999.

7 Counter-Memorial Submitted by the Republic of Serbia, December 2009, Chapter XIV.

8 Application of the Convention on the Prevention and Punishment of the Crime of Genocide (Croatia v Serbia), Preliminary Objections, Judgment, ICJ Reports 2008, 412. In its first preliminary objection, Serbia claimed that the Court lacked jurisdiction. Serbia's second and third preliminary objections were in the alternative. In its second preliminary objection Serbia claimed that the acts or omissions that took place before 27 April 1992 were outside of the Court's jurisdiction and inadmissible. In its third preliminary objection, Serbia argued that claims referring to the trial of certain persons within Serbia's jurisdiction, the provision of regarding the whereabouts of missing Croatian citizens, and the return of cultural property were outside of the Court's jurisdiction and inadmissible. 
outside the scope of the Genocide Convention, and therefore outside the Court's jurisdiction. The Court not only declined to rule on this issue at the preliminary objections stage, but it also avoided the issue at the merits stage.

Serbia based its challenge to the Court's temporal jurisdiction on a declaration by the FRY on 27 April 1992. In its declaration, the FRY proclaimed its status as the continuator of the Socialist Federal Republic of Yugoslavia (SFRY) and declared that it would fulfill all of the international legal obligations assumed by the SFRY. ${ }^{9}$ In its judgment on preliminary objections, the Court determined that this declaration served as a notification of the FRY's succession to treaties to which the SFRY was a party, including the Genocide Convention. ${ }^{10}$ However, the Court's 2008 judgment went no further than this. The Court decided that it would "need to have more elements before it" in order to determine whether the Genocide Convention applied to the FRY before 27 April 1992, and what the consequences would be for the FRY under the rules of state responsibility. ${ }^{11}$ The Court therefore reserved Serbia's second preliminary objection for the merits because it did not possess "an exclusively preliminary character". 12

At the merits stage, the Court emphasized that the Genocide Convention's compromissory clause, contained in Article IX, provided the only basis for jurisdiction in this case. ${ }^{13}$ In the Court's determination, this had two consequences. ${ }^{14}$ First, the dispute had to concern the interpretation, application or fulfillment of the Genocide Convention, as required by Article IX. ${ }^{15}$ Second, the dispute had to concern obligations under the Convention itself, rather than obligations under customary international law on genocide. ${ }^{16}$ The Court noted that the dispute "would appear to fall squarely within the terms of Article IX" because the dispute's "essential subject-matter" is whether Serbia is responsible for violations of the Con-

92015 Judgment para 76.

102008 Judgment para 111.

112008 Judgment para 129.

122008 Judgment para 146, point 4.

132015 Judgment para 84. Article IX of the Genocide Convention provides that: 'Disputes between the Contracting Parties relating to the interpretation, application or fulfillment of the present Convention, including those relating to the responsibility of a State for genocide or for any of the other acts enumerated in article III, shall be submitted to the International Court of Justice at the request of any of the parties to the dispute.

142015 Judgment para 85.

15 Ibid., paras $85,89$.

16 Ibid., paras 87-89. 
vention. ${ }^{17}$ But it also determined that the compromissory clause does not serve as "a general provision for the settlement of disputes" with no temporal limitation. ${ }^{18}$ The Court found that the temporal scope of Article IX is linked to the temporal scope of the Convention's provisions, which do not apply retroactively to acts that occurred before a State became bound by the Convention. ${ }^{19}$

The Court then addressed Croatia's claims that acts or omissions that occurred before 27 April 1992 may still fall within the scope of Article IX. Croatia based this argument on Article 10(2) of the International Law Commission's Articles on State Responsibility, which concerns the attribution of the conduct of a movement that succeeds in establishing a new State. ${ }^{20}$ Article $10(2)$ provides that " $\left.t \mathrm{t}\right]$ he conduct of a movement, insurrectional or other, which succeeds in establishing a new State in part of the territory of a pre-existing State or in a territory under its administration shall be considered an act of the new State under international law". According to Croatia, the "Greater Serbia" movement, which took control of the Yugoslav's People's Army (JNA) and the SFRY, eventually succeeded in creating the FRY, which bears State responsibility for acts or omissions attributable to the movement. ${ }^{21}$ The Court, however, rejected Croatia's argument due to its finding that Article 10(2) concerns only the attribution of conduct, not the creation of obligations binding on the movement or the new State. ${ }^{22}$ Conduct attributable to the "Greater Serbia" movement could have only involved violations of the customary international law prohibition on genocide, and not the Genocide Convention, to which the movement was not a party. ${ }^{23}$ On account of this conclusion, the Court did not address the question of whether Article 10(2) formed part of customary international law in 1991-1992 or thereafter. $^{24}$

The Court then turned to Croatia's alternative argument that the FRY succeeded to the responsibility of the SFRY for acts or omissions prior to 27 April 1992 that were attributable to the SFRY and in breach of the SFRY's obligations under the Genocide Convention. ${ }^{25}$ At this point, the

17 Ibid., para 90.

18 Ibid., para 93.

19 Ibid., paras 93, 100.

20 Ibid., paras 102-105.

21 Ibid., para 102.

22 Ibid., para 104.

23 Ibid., para 105.

24 Ibid., para 105.

25 Ibid., para 106. 
Court explained that it was in possession of the "additional elements" needed to distinguish between issues of jurisdiction and the merits, and to make findings on these issues. ${ }^{26}$ These additional elements were missing during the preliminary objections phase in 2008, but after further written pleadings and oral arguments on the merits, the Court was apparently satisfied with the "elements" before it, though it did not elaborate. ${ }^{27}$

The Court decided that the jurisdictional question must be confined to whether the dispute between the Parties falls within Article IX of the Genocide Convention, which covers disputes about the treaty's interpretation, application, and fulfillment. The Court boiled down this dispute to three contested points:

(1) whether the acts relied on by Croatia took place; and if they did, whether they were contrary to the Convention;

(2) if so, whether those acts were attributable to the SFRY at the same time that they occurred and engaged its responsibility; and

(3) if the responsibility of the SFRY had been engaged, whether the FRY succeeded to that responsibility. ${ }^{28}$

The Court then determined that these three issues fall "squarely" within the Court's jurisdiction ratione materiae under Article IX, as they involve matters of breach, attribution, and the responsibility of the SFRY. ${ }^{29}$ The Court further explained that the third issue, concerning succession to responsibility, raises serious questions of law and fact that form part of the merits of the dispute and require a decision only after the first two issues concerning breach and attribution have been decided. ${ }^{30}$ Moreover, the Court determined that this dispute concerning succession to responsibility falls within the scope of Article IX even though it is governed not by the Convention's provisions, but by rules of general international law, like the rules on treaty interpretation and State responsibility. ${ }^{31}$ Because the Convention itself does not specify when State responsibility arises, the Court decided that it must look to general international law in order to resolve this issue.

26 Ibid., para 110.

27 Ibid., para 110; see also Separate Opinion of President Tomka, paras 3-4.

282015 Judgment para 112.

29 Ibid., para 113.

30 Ibid., para 114.

31 Ibid., para 115. 
Finally, the Court rejected Serbia's contention that the Monetary Gold principle applied in this case. As the Court explained it, this principle means that the Court cannot adjudicate where doing so would be "contrary to the right of a State not party to the proceedings to not have the Court rule upon its conduct without its consent" ${ }^{32}$ The Court dismissed the relevance of this principle because the SFRY no longer exists, and therefore no longer has any rights or the capacity to give or withhold consent to the Court's jurisdiction. ${ }^{33}$ Furthermore, the Court considered that ruling on the "legal situation" of the other successor States to the SFRY was not a "prerequisite" in order to determine the present claim. ${ }^{34}$

The Court concluded its finding that it had jurisdiction over acts that occurred before 27 April 1992 by noting that questions about breach, attribution and succession to responsibility are all matters for the merits. ${ }^{35}$ Six of the seventeen judges on the bench dissented from the Court's ruling that it had jurisdiction to entertain Croatia's claims concerning conduct that occurred prior to 27 April 1992, and their separate and dissenting opinions and declaration on this issue suggest that it was a matter of considerable controversy during deliberations. ${ }^{36}$ On the merits of the dispute, the Court held that while Croatia and Serbia had both established the requisite actus reus for genocide, in support of their claim and counterclaim, respectively, they had not proven the requisite mens rea. The Court therefore rejected Croatia's claim and Serbia's counterclaim, and never reached the final issue in contention-succession to responsibility.

\section{A Critique of the Court's Treatment of the Issue of Succession to Responsibility}

The Court's approach to the issue of succession to responsibility may be questioned on at least two grounds. ${ }^{37}$ First, the manner in which the Court ordered the issues in contention between the parties allowed it to shift a

32 Ibid., para 116.

33 Ibid., para 116.

34 Ibid., para 116.

35 Ibid., para 117.

36 President Tomka; Judges Owada, Skotnikov, Xue, Sebutinde; Judge ad hoc Kreca.

37 For a broader discussion of other jurisdictional and procedural aspects of this case, see Bordin, F.L. (2015), "Procedural Developments at the International Court of Justice", The Law and Practice of International Courts and Tribunals 14(2), 340 . 
preliminary, jurisdictional issue to the end of its inquiry, and ultimately beyond the scope of the judgment. Second, the Monetary Gold principle may have had more relevance in this case than the Court allowed.

\section{a. The Court's Sequencing of the Issues in Contention}

Reordering the issues in contention is, in fact, a judicial technique that the Court has employed on numerous occasions to achieve various ends. By altering the sequence in which it considers the issues before it, the Court can ensure that it avoids undesirable issues, or that it reaches issues that would not otherwise come under consideration. The Oil Platforms case is an apt illustration of the latter possibility. ${ }^{38}$

The dispute in Oil Platforms concerned Article X, paragraph 1 of the 1955 Treaty of Amity, Economic Relations and Consular Rights between the United States and Iran, which provides that "[b]etween the territories of the two High Contracting Parties there shall be freedom of commerce and navigation" 39 . Iran alleged that the United States had breached this provision by attacking and destroying Iranian oil platforms in 1987 and 1988. The United States, however, claimed that these were justified acts of self-defence in response to armed attacks by Iran..$^{40}$ The basis for this argument by the United States was paragraph 1(d) of Article XX, which could be characterized as an exception to Article X, paragraph 1 . Article XX, paragraph $1(\mathrm{~d})$ provides that " $[\mathrm{t}]$ he present Treaty shall not preclude the application of measures... necessary to fulfill the obligations of a High Contracting Party for the maintenance or restoration of international peace and security, or necessary to protect its essential security interests".

Ordinarily, the Court might be expected to determine the existence of a breach before examining whether the breach may be justified on grounds of self-defence. ${ }^{41}$ In this case, however, the Court decided that "particular considerations" militated in favour of examining the issue of self-defence

38 Oil Platforms (Islamic Republic of Iran $v$ United States of America), Judgment, ICJ Reports 2003, 161.

39 Ibid., para 31.

40 Ibid., para 37.

41 See, e.g., the Court's treatment of substantially identical provisions in the 1956 Treaty of Friendship, Commerce and Navigation between the United States and Nicaragua. Military and Paramilitary Activities in and against Nicaragua (Nicaragua v. United States of America), ICJ Reports 1986, 117, para 225. 
before examining the issue of breach. ${ }^{42}$ The Court took into consideration the fact that the original dispute between the parties related not to the 1955 Treaty of Amity, but to the legality of the use of force by the United States. ${ }^{43}$ The Court further emphasized that the issues of self-defence presented in this case "raise matters of the highest importance to all members of the international community" and had important implications for the field concerning the use of force. ${ }^{44}$ Perhaps in light of the fact that the March 2003 US invasion of Iraq took place just days after the oral proceedings in this case ended and its deliberations began, the Court appears to have attached special importance to addressing issues relating to the use of force-even if doing so required it to consider the parties' claims out of their logical sequence. ${ }^{45}$

The Court ultimately determined that it could uphold neither the claims made by the United States on grounds of self-defence, nor Iran's assertions that those actions breached the obligation of freedom of commerce under the 1955 Treaty. ${ }^{46}$ Had the Court dealt with the issue of breach first, then there would have been no need for it to proceed to the question of whether the actions of the United States could be justified. As a matter of judicial economy, this ordering of the issues would have been more efficient. But the Court noted that it has freedom to select the ground on which it will base its judgment. ${ }^{47}$ In this case, the Court opted to base its judgment on two grounds, seemingly for the sake of ensuring that it reached issues of use of force, due to their importance in the particular case, and also at this moment in history. The Court's unusual approach prompted a third of the bench to discuss their concerns about the Court's ordering of the issues in separate opinions, and it also gave rise to scholarly criticism. ${ }^{48}$

42 Oil Platforms, supra note 38, para 37.

43 Ibid.

44 Ibid., para 38.

45 See, e.g., Separate Opinion of Judge Simma, para 6.

46 Oil Platforms, supra note 38, para 125(1).

47 Ibid., para 37, quoting Application of the Convention of 1902 Governing the Guardianship of Infants, Judgment, ICJ Reports 1958, 62.

48 Separate opinions of Judges Buergenthal, Higgins, Kooimans, Owada, and ParraAranguren; see also Small, D.H. (2004), "The Oil Platforms Case: Jurisdiction Through the - Closed - Eye of the Needle", The Law and Practice of International Courts and Tribunals 3(1), 113; Taft, W.H., IV (2004), "Self Defense and the Oil Platforms Decision", Yale Journal of International Law 29(2), 295; but see Separation Opinion of Judge Simma. 
In Croatia v Serbia, the same judicial technique allowed the Court not only to reach the parties' substantive claims about the commission of genocide, but also to avoid the issue of temporal jurisdiction. The Court ordered the issues in contention so that the first two issues requiring examination were breach and attribution, while the question of state succession to responsibility followed in third place. The Court's sequencing is both surprising and counter-intuitive. The issue of state succession to responsibility amounts to a question concerning the Court's temporal jurisdiction. The question whether Serbia could succeed to the responsibility of the FRY for acts that occurred pre-April 1992 had direct bearing on the scope of the Court's temporal jurisdiction over Serbia. The extent of the Court's temporal jurisdiction was especially important in this case because the bulk of the acts alleged by Croatia took place before 27 April 1992.

The Court's sequencing is surprising because the Court had previously treated the issue of state succession to responsibility as a jurisdictional question, albeit a jurisdictional question that did not possess an exclusively preliminary character. The Court's 2008 judgment implied that this question was appropriate for consideration at the merits stage because it was closely linked with the merits of the case and the Court required more information in order to rule on the issue. Having apparently acquired additional information at the merits stage, one would still expect to see the Court take up this question as a threshold issue, before examining breach and attribution. Questions concerning the Court's temporal jurisdiction should logically be considered prior to questions of breach and attribution, as the Court cannot otherwise be assured that it has jurisdictional competence to determine whether an internationally wrongful act has occurred. The Court's sequencing is also counter-intuitive because jurisdictional issues are always threshold issues, even when they do not have an exclusively preliminary character and thus require additional information linked to the merits.

The Court justified its sequencing with some questionable, and also quite limited, legal reasoning. In essence, the Court excised the issue of state succession to responsibility from the jurisdictional questions before it, and merged the issue with the merits. In the Court's view, the jurisdictional question before it at the merits stage was confined to whether the issues in contention concerned the interpretation, application or fulfillment of the Genocide Convention, as required by Article IX. The sole jurisdictional question before the Court was therefore limited to its subject matter jurisdiction, or jurisdiction ratione materiae. By identifying succession to responsibility as an issue falling within the scope of its subject matter jurisdiction, along with breach and attribution, the Court re-character- 
ized it as a question for the merits. Along the way, the Court dropped the term jurisdiction ratione temporis, and instead referred to this issue as one concerning state succession to responsibility.

The Court's jurisdictional maneuver ensured that it never reached the issue of state succession to responsibility, as its inquiry began and ended with an examination of the first issue in contention-whether the two states breached the Genocide Convention. After determining that the mens rea necessary for breach had not been proven by either party, there was no need for the Court to proceed to the second and third issues in contention. The judgment therefore leaves open the possibility that its rulings on incidents that took place prior to April 1992 may have actually exceeded its temporal jurisdiction. Given the lack of certainty among the judges of the Court and in academic circles about the existence of a rule on state succession to responsibility, this is a very real possibility. ${ }^{49}$ Without delving into this legal debate, this chapter proceeds under the assumption that the existence of such a rule is uncertain.

The ramifications of the Court's approach would have become clearer had the Court actually attributed wrongful conduct to the SFRY, but then determined that Serbia could not be held responsible for the wrongful acts of the SFRY on account of the absence of a rule of state succession to responsibility. In these circumstances, the Court's ruling on the responsibility of a third party not before the Court-the SRFY - might have had direct consequences for all of the successor states of the SFRY. ${ }^{50}$ This brings us to the second part of this critique, concerning the Monetary Gold principle, which the Court dismissed partly on account of the fact that the SFRY no longer exists.

\section{b. The Court's Treatment of the Monetary Gold Principle}

While the Monetary Gold principle may not have applied to the circumstances of this case, this was not on account of the SFRY's disappearance. Given the existence of five successor States to the SFRY, all of which may potentially be allocated responsibility for claims against the SFRY, the SFRY has not actually disappeared for legal purposes. In the Monetary Gold

49 Separate Opinion of Judge Skotnikov, para 4; Paddeu, F. (2015), "Ghosts of Genocides Past? State Responsibility for Genocide in the Former Yugoslavia”, Cambridge Law Journal 74(2), 198, 200-201.

50 Separate Opinion of President Tomka, para 32. 
case the Court held that adjudicating on the international responsibility of a third party "without her consent would run counter to a well-established principle of international law embodied in the Court's Statute, namely, that the Court can only exercise jurisdiction over a State with its consent" ${ }^{\prime \prime}$. In this case, the legal interests of the third party, Albania, would not only have been affected by the Court's decision, but would have been "the very subject-matter of the decision" 52 . Since the Monetary Gold case, the Court has applied this principle in a rather case-by-case, nuanced manner. ${ }^{53}$

In Croatia v Serbia, the Court determined that the Monetary Gold principle was inapplicable in part because the SFRY no longer exists, and therefore does not have any rights, and cannot consent to the Court's jurisdiction. Undoubtedly, a state that no longer exists cannot consent to jurisdiction. But the rights and obligations of a former state do not necessarily disappear when the state ceases to exist. ${ }^{54}$ To the extent that former states have outstanding assets and liabilities, archives, and former employees with pensions, for example, former states can and do live on from a legal perspective. Most significantly, for the purposes of the dispute between Croatia and Serbia, former states can have outstanding obligations-a fact that went unmentioned in the Court's judgment. An obligation to make reparations could, for example, arise out of a determination that the SFRY committed internationally wrongful acts prior to April 1992. Had the Court held the SFRY responsible for acts of genocide, then such a ruling potentially could have implicated all successor states. In particular, the successor states might have been implicated had a ruling by the Court on the SFRY's responsibility been coupled with a ruling that Serbia did not succeed to the SFRY's responsibility.

51 Monetary Gold Removed from Rome in 1943, Preliminary Question, Judgment, ICJ Reports 1954, 19, 22.

52 Ibid.

53 See, e.g., Certain Phosphate Lands in Nauru (Nauru v. Australia), Preliminary Objections, Judgment, ICJ Reports 1992, 240; East Timor (Portugal v. Australia), Judgment, ICJ Reports 1995, p. 90; Thienel, T. (2014), "Third States and the Jurisdiction of the International Court of Justice: The Monetary Gold Principle", German Yearbook of International Law 57, 321; Orakhelashvili, A (2011), "The Competence of the International Court of Justice and the Doctrine of the Indispensable Party: from Monetary Gold to East Timor and Beyond", Journal of International Dispute Settlement 2(2), 373.

54 Declaration of Judge Xue, paras 24-25. 
Moreover, the existing succession agreement between the five successor states to the SFRY likely would not cover such legal obligations. In 2001, the successor states (Bosnia and Herzegovina, Croatia, Macedonia, Slovenia, and the FRY) concluded an Agreement on Succession Issues. While this agreement covers a range of issues, including financial assets and liabilities, an obligation to provide compensation or some other form of reparation for acts of genocide committed by the SFRY would likely fall outside of the scope of the Agreement. The Agreement, however, provides that claims against the SFRY, which are not otherwise covered, shall be considered by a Standing Joint Committee established in accordance with the Agreement. ${ }^{55}$ The practical consequences of a finding of responsibility against the SFRY would therefore be quite uncertain. While a claim against the SFRY would be a claim against all successor states, the Standing Joint Committee would, of course, have to grapple with the complicating fact that both parties are themselves successor states (Croatia and Serbia, respectively).

If the Court had attributed wrongful conduct to the SFRY, then the rights and obligations of all of the successor States would potentially have been impacted by the Court's ruling. But whether such a ruling would have actually conflicted with the Monetary Gold principle, thereby rendering the claims inadmissible, is debatable in light of the Court's varied jurisprudence concerning this rule. While the attribution of responsibility to the SFRY would have had implications for the legal situation of the successor states, the rights and obligations of all five successor states would not necessarily have been the "very subject matter" of the Court's ruling. ${ }^{56}$ In other words, a ruling by the Court on the SFRY's responsibility would not have been based on a determination regarding the legal situation of the five successor states, though it might have had implications for them. The Court thus upheld a distinction between rulings that are based on determinations regarding the legal situations of third parties, and rulings that merely have implications for the legal situation of third parties. One may question, however, whether such a distinction is really sustainable in cases involving succession from a federal entity. The SFRY lives on, from a legal perspective, in the form of its five successor states, such that rulings about reparations owed by the SFRY arguably amount to rulings about reparations owed by its successor states. Regardless, the point to be emphasized

55 Agreement on Succession Issues, Annex F, art 2.

56 Such a ruling would have arguably been in keeping with Certain Phosphate Lands in Nauru, para 55. 
here is that the Monetary Gold principle did not lose its relevance simply because the SFRY no longer exists. The applicability of the Monetary Gold principle is indeed debatable in this instance, but not on account of the SFRY's non-existence. Both the brevity and the substance of the Court's reasoning on this issue may be taken as another example of its willingness to skirt jurisdictional issues, and in particular succession to responsibility, in this judgment. Moreover, had the Court considered the issue of succession to responsibility, and found that such a rule exists, then its discussion of the Monetary Gold principle might have been more nuanced.

\section{The Court as Fact-Finder}

If the Court had addressed the issue of state succession to responsibility in the section on jurisdiction and admissibility, before reaching the merits of the case, its judgment might have come to an early end. To the disappointment of many, sixteen years of litigation, concerning events of great importance for the states concerned, might have ended with a finding by the Court that it lacked temporal jurisdiction over most of the alleged acts of genocide. In deciding to order the issues as it did, the Court, of course, knew what its rulings would be on the three issues in contention. The judges would have already determined that the parties had failed to prove the requisite mens rea for genocide, thus foreclosing the need for it to proceed further, to the issue of state succession to responsibility. By examining the issue of breach first rather than second (after the issue of temporal jurisdiction), the Court greatly extended the length of the judgment, and delved into the merits of the case. The Court's jurisdictional maneuver effectively allowed it to reach the substance of the parties' claims about the commission of genocide. ${ }^{57}$

From the perspective of the Court's role as a dispute settlement body, its approach to the case demonstrates that in certain circumstances, its insistence on the need for consent may waver. The thoroughness or coherency of its findings on jurisdiction may bear some connection to the significance of the parties' substantive claims. The Court's various and inconsistent rulings on jurisdiction in another case involving allegations of acts of

57 See also Van den Herik, L. (2015), "Introductory Note to Application of the Convention on the Prevention and Punishment of the Crime of Genocide (Croatia v Serbia) (ICJ)", International Legal Materials 54(5), 787, 789. 
genocide-the Bosnia Genocide case-have also raised eyebrows. ${ }^{58}$ In Croatia $v$ Serbia, the Court's willingness to sidestep a potentially significant jurisdictional obstacle allowed it to examine the parties' factual allegations, which it did in relatively great depth, over the course of approximately 70 pages.

The judgment's main contribution to the settlement of the dispute between the parties therefore consists primarily in establishing an authoritative record of what occurred during the conflict between Croatia and Serbia. The Court methodically considered, region by region, whether specific acts met the actus reus for genocide under Article II of the Genocide Convention, before determining that the requisite genocidal intent (dolus specialis) was missing. As a document that primarily serves as a record of the atrocities that took place in the early to mid-1990s in Croatia and in the Republic of Serbian Krajina, the judgment arguably resembles the reports of commissions or panels of inquiry. This is not to say that the Court merely establishes a factual record without providing legal rulings. Indeed, the Court does make legal assessments (as do many commissions of inquiry, for that matter). But the judgment's primary contribution is arguably factual rather than legal in part because the Court had already worked through many of the relevant legal issues in the 2007 Bosnia Genocide judgment. The Court's judgment in Croatia v Serbia does not significantly advance our understanding of the legal aspects of state responsibility for genocide beyond the Bosnia Genocide case. It does, however, provide an authoritative account of certain aspects of the conflict in Croatia and the Republic of Serbian Krajina, by drawing together witness statements, findings of the International Criminal Tribunal for the former Yugoslavia, etc. But the Court's apparent willingness in this case to engage with a relatively vast and complex evidentiary record should be distinguished from the manner in which the Court went about assessing the evidence, which has been the subject of some criticism (and which lies beyond the scope of this chapter). 59

58 Separate Opinion of Judge Skotnikov, paras 8-9; Bordin, F.L. (2011), "Continuation of Membership in the United Nations Revisited: Lessons from Fifteen Years of Inconsistency in the Jurisprudence of the ICJ", The Law and Practice of International Courts and Tribunals 10(2), 315.

59 Gattini, A. and Cortesi, G. (2015), "Some New Evidence on the ICJ's Treatment of Evidence: The Second Genocide Case", Leiden Journal of International Law 28(4), 899. 
In light of the Court's prior judgment in the Bosnia Genocide case, the parties in Croatia v Serbia must have suspected that their claims would fall short of what the Court requires for a showing of genocidal intent. The Court set a high bar for proving mens rea in the Bosnia Genocide case, and Croatia and Serbia could not have reasonably expected the Court to depart from this jurisprudence. Given that the parties could have foreseen the Court's rulings on the issue of breach, one might have expected the parties to discontinue their litigation after the Court's 2007 Bosnia Genocide judgment, by agreeing to an out-of-court settlement. ${ }^{60}$ Perhaps an authoritative account of the atrocities committed during the conflict was, in good part, what the parties sought through litigation at the ICJ.

The argument here is not that the Court refashioned itself as a commission of inquiry. This would be an unsustainable position in part because commissions of inquiry generally refrain from making rulings on state responsibility. Instead, this chapter pursues the possibility that the judgment's most significant contribution to dispute settlement was factual rather than legal, in much the same way that commissions of inquiry contribute to dispute settlement by providing an authoritative account of disputed facts.

\section{Conclusion}

The case of Croatia $v$ Serbia fits somewhat uneasily with the conception of the ICJ as an institution that is highly deferential to state sovereignty and whose activities are justified by state consent. In this case, a plausible, if not strong argument could be made that the Court lacked temporal jurisdiction over many of the claims made by Croatia. The Court, however, employed a jurisdictional maneuver that allowed it to bypass this jurisdictional obstacle, and to reach some aspects of the merits of the parties' claims. In doing so, the Court displayed a weaker attachment to the importance of consent than one might expect, and its judgment took on a distinctly fact-heavy character, not unlike reports of commissions of inquiry.

60 For one explanation of why the parties failed to agree to an out-of-court settlement, see Simons, M. (2015), "Croatia and Serbia Cleared of Genocide by Hague Court", The New York Times, 3 February ("Serbia has long been trying to work on an out-of-court settlement rather than continue the costly legal proceedings. Some political leaders in Croatia have said privately they agreed, but they could not be seen dropping the genocide case for fear of ridicule as weaklings and traitors by the opposition"). 
All of this suggests that the standard account of international courts as dispute settlers may benefit from greater nuance. In issuing an authoritative account of the events in dispute, the Court may have also signaled an awareness of the import of the allegations made by the parties. However, the Court also displayed an awareness of the fact that it might have been untenable, from a public relations perspective, to decline to rule at such a late stage on the bulk of Croatia's allegations due to a lack of jurisdiction. In this case, the Court appears to have ruled in the name of the states whose governments could not manage to settle this case throughout many years of litigation, and also in the name of their newspaper-reading citizens, for whom a decision not to rule on the merits would have been difficult, if not impossible to explain. 